\title{
Job Satisfaction of Agricultural Professionals in Commercial Banks of Kerala
}

\author{
Vagvala Suryaja $^{1}$ and Allan Thomas ${ }^{2}$
}

\begin{abstract}
The study was conducted in Thiruvananthapuram district of Kerala, to analyse the factors affecting job satisfaction of agricultural professionals in commercial banks of Kerala. Ninety agricultural professionals working in two major banks viz., State Bank of India and Canara Bank were randomly selected. Ex-post facto research design was followed. It was found that about fifty per cent of respondents felt that they have high job satisfaction. The results of the Principal Component Analysis based on eigen values obtained revealed that all the five components viz., pay, promotion, work, supervision and people were the factors influencing job satisfaction.
\end{abstract}

Keywords: Job satisfaction; agricultural professionals; bank;performance; promotion; Kerala

\section{INTRODUCTION}

Banking sector is an important sector in Indian economy. It is considered to be reputed, sophisticated and less corrupted profession. Youngsters especially agricultural graduates find it one of the most reliable job opportunities and are fascinated in getting an agricultural field officer or rural development officer job in various public sector banks. Banks are diversifying their role in the agriculture sector. Some of the new roles that banks have adopted are marketing, training and consultancy, insurance, and financing for infrastructure via private - public participation. Changing environment and government policies are forcing banks to lend more to agricultural sector. Agricultural field officers and bank managers are always supporting and assisting farmers in day to day credit related activities and timely sanction of loans. Their performance, job satisfaction, quality of work life should be enhanced, which in turn improves the services provided to farmers. Job performance of employees is positively related to job satisfaction and the same is inferred in studies by Nadef (2018) and Patel (1999). The present study on job satisfaction of agricultural professionals in commercial banks of Kerala becomes important that will aid in deep analysis on the problems faced by agricultural professionals in bank.

1. PG Scholar and 2. Assistant Professor (Sel. Grade), Department of Agricultural Extension, College of Agriculture, Vellayani, Thiruvananthapuram- 695522. Kerala.

Received : 24-07-2018; Accepted : 25-10-2018 
Job Satisfaction of Agricultural Professionals in Commercial Banks of Kerala

\section{METHODOLOGY}

Thiruvananthapuram district in Kerala was purposefully selected for the study because being the capital of the state most of the headquarters of the public sector commercial banks were located at this place. Variables, both independent and dependent were selected based on objectives of study and literature search. Survey method was employed for data collection. A pretested, structured questionnaire was prepared and administered to the respondents of the study. Google forms were also used for data collection from distant respondents. Ex-post facto research design was adopted for the study.

Forty-five branches were selected with 30 branches from State bank of India (SBI) and 15 branches of Canara bank. More number of branches from SBI were included because it is the bank with more number of branches compared to any other commercial public sector banks. Thus, 60 bank officials from State Bank of India and 30 bank officials from Canara bank dealing with agricultural products were randomly selected for the study making a sample size of 90 respondents.

The main dependent variable of the study was job satisfaction of agricultural professionals. Independent variables of the study were age, education, monthly income, sex, experience, marital status, number of dependents, distance from work place, residential status, dwelling status, working hours and work load.

The scale developed by Smith (1974) was used for computing the job satisfaction. It consists of 5 components viz., pay, promotions, work, supervision and people. Each component consists of 8 items, therefore making it 40 statements. All statements were ranked on scale of 0 to 5 . Scores varied from 40 to 200 . All the scores were cumulated to find the final score of job satisfaction and the respondents were categorised into low and high category of job satisfaction based on below and above mean values.

\section{FINDINGS AND DISCUSSSION}

Job satisfaction was dependent variable of the study. It is clear from Table 1 that 54.44 per cent of agricultural professionals in banks belonged to above mean (high) and about 45.56 per cent were grouped under below mean (low) for the component structure of job satisfaction.Agricultural professionals were grouped into high-low categories based on mean value as check and the data are presented in Table 1.

Table 1.

Distribution of Agricultural Professionals based on Job Satisfaction

$(n=90)$

\begin{tabular}{|c|l|l|l|}
\hline SI. No. & \multicolumn{1}{|c|}{ Category } & \multicolumn{1}{c|}{ Frequency } & \multicolumn{2}{c|}{$\%$} \\
\hline 1 & High & 49 & 54.44 \\
\hline 2 & Low & 41 & 45.56 \\
\hline 3 & Mean $=80.33 ;$ Standard deviation $=21.71 ;$ Standard Error $=2.28$ \\
\hline
\end{tabular}


Table 1 reveals that all the five factors viz., pay, promotion, work, supervision and peoplewere the contributors for the high mean value of job satisfaction. Mean value of job satisfaction for all the five components together was 80.33. Though it is certain from Table 1 that 45.56 per cent of the respondents belonged to low category of job satisfaction, there could have been a situation where the respondents belonging to the low category of job satisfaction could have realized a score higher or close to mean value of job satisfaction score (80.33).

From the results of the variablity from PCA as revealed in Table 2, it is inferred that component one was responsible for 48.41 per cent variability, component two was responsible for 23.74 per cent variability and component three was responsible for 14.72 per cent variability.

Table 2 and Fig.1 depicting the cumulative variance clearly reveal that the first three components contributed to more than 80 per cent variability. It is interesting to note that the eigen values drawn through PCA established the fact that all the five

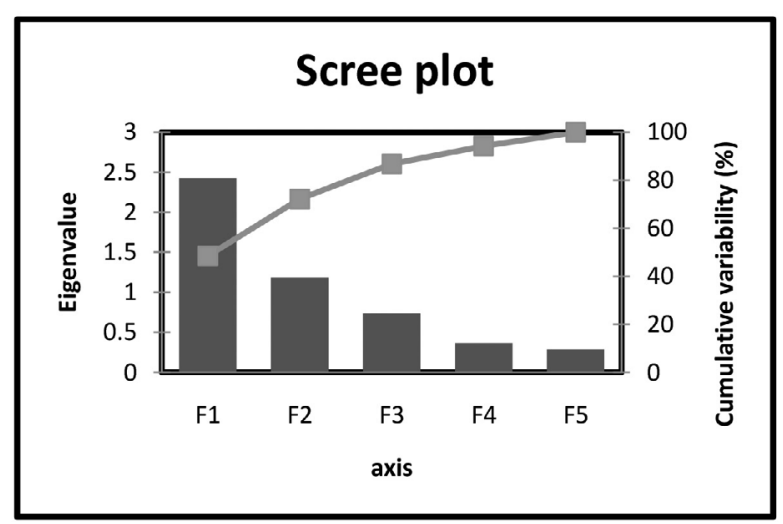

Figure 1. Total variance of components of Job Satisfaction

components viz., pay, promotion, work, supervision and people were the factors influencing job satisfaction and its results are presented in Table 3.

From Table.3 it is evident that from first component, promotion (0.512) has highest eigen value followed by supervision (0.490), from second component, pay (0.759) was having highest eigen value and from third component, people (0.682) and work (0.590) were having highest eigen values. This shows that all the component factors influenced the job satisfaction of bank professionals. Promotion gives employees a chance to explore

Table 2

Total Variance of Components of Job Satisfaction

$(n=90)$

\begin{tabular}{|c|c|c|c|}
\hline \multirow{2}{*}{ Component } & \multicolumn{3}{|c|}{ Initial Eigen values } \\
\cline { 2 - 4 } & Total & \% of Variance & Cumulative \% \\
\hline 1 & 2.420 & 48.41 & 48.41 \\
\hline 2 & 1.187 & 23.74 & 72.15 \\
\hline 3 & .736 & 14.72 & 86.87 \\
\hline 4 & .366 & 7.32 & 94.19 \\
\hline 5 & .291 & 5.81 & 100.00 \\
\hline
\end{tabular}


Job Satisfaction of Agricultural Professionals in Commercial Banks of Kerala

Table 3

Eigen values of each Factor of Job Satisfaction.

\begin{tabular}{|l|c|c|c|}
\hline \multirow{2}{*}{\multicolumn{1}{c|}{ Factors of Job Satisfaction }} & \multicolumn{3}{c|}{ Component } \\
\cline { 2 - 4 } & $\mathbf{1}$ & $\mathbf{2}$ & $\mathbf{3}$ \\
\hline Pay & 0.296 & 0.759 & -0.017 \\
\hline Promotion & 0.512 & 0.317 & -0.357 \\
\hline Work & 0.430 & 0.418 & 0.590 \\
\hline Supervision & 0.490 & 0.384 & 0.242 \\
\hline People & 0.474 & 0.041 & 0.682 \\
\hline
\end{tabular}

new areas of work that indeed improves overall working conditions and contributors to job satisfaction. Frederick Herzberg's (1966) two factor theory states that work place motivation and employees recognition were effective in satisfying employees needs that further ensures positive attitude towards work. Hence the study endorses the views of Maslow (1954) and Mc Gregor (1960). Bank employees exhibit high job satisfaction when encouraged and supported by their supervisors. Hence, supervision becomes a factor of influence on job satisfaction which falls in line with the study of Sowmya and Panchanatham (2011). Pay is the obvious motivating factor behind employee's attitude to serve the customers even when they are overloaded. Many studies revealed that salary is one of the prime reasons that bring about employees satisfaction and retention. Studies by Judge et al. (2010), Swami et al. (2015) and Sudha (2017) inferred the same. Employees had significant inclination towards optimistic supervising behaviour. Employees tend to be satisfied at work if they find commonalities among their co-workers and supervisors. People act as vent for stressed employees and aid each other in creating positive atmosphere at work place. Therefore, as people are the support system for any organisation, interpersonal relationships could be stated as an influencing factor affecting job satisfaction.

\section{CONCLUSION}

The Indian banking sector is at an exhilarating point in evolution. The opportunities are immense to enter new business, to develop new ways of working, to improve efficiency and to deliver high level of customer service. Therefore the interdependence of all stakeholders of banking system is increasing. Kerala farmers being more literate and sensitive to social issues are believed to be more demanding and in the course to satisfy the need of the farmers the bank officials are subjected to different challenges and issues. From this study we can infer that all the five factors viz., pay, promotion, work, supervision and people are influencing the job satisfaction of banking professionals. Necessary steps and policy changes can be adopted to improve the banking systems by focusing more on these factors inorder to incarnate the banking professionals to be more effective and farmer 
friendly. Also, it will satisfy the needs of agricultural professionals to perform better contributing to the nations economy.

\section{REFERENCES}

Herzberg, F. (1966). Work and the Nature of Man. New York: Mc Graw Hill, p 118.

Judge, T. A., Piccolo, R.F., Podsakoff, N.P., Shaw, J.C., \& Rich, B.L. (2010). The relationship between pay and job satisfaction: A meta- analysis of the literature. Journal of Vocational Behavior. 77(2), 157-167.

Maslow, A.H. (1954). Motivation and Personalities. New York; Harper and Row Publishers, pp 176.

Mc Gregor, D. (1960). The Human Side of Enterprise. New York; Mc Graw Hill, pp 118.

Nadef, Z.A. (2018).Comparative study on job satisfaction of $J \& K$ bank employees. North Asian International Research Journal of Social Science \& Humanities. 4(1), 281-293.

Patel, M.K. (1999). A study of impact of age on job involvement and organizational commitment of Nationalized and Cooperative bank employees.Journal of Indian Academy of Applied Psychology. 25(12),65-70.

Smith, P.C. (1974). The development of measuring job satisfaction; The Cornell Studies. In E.A. Fleishman\& A.R. Bass(Eds.) Studies in personnel and industrial psychology (3rd ed). Homewood, IL: Dorsey.

Sowmya, K. R., \& Panchanatham, N. (2011). Factors influencing job satisfaction of banking sector employees in Chennai, India. Journal of Law and Conflict Resolution. 3(5),76-79.

Sudha, V. (2017). Factors determining job satisfaction among private sector bank employees. International Educational Research Journal. 3(3),31-32.

Swamy, D.R., Nanjundeswaraswamy, T. S., \& Rashmi, S. (2015). Quality of work life: scale development and validation. International Journal of Caring Science. 8(2),281-286. 